\title{
An enigmatic, possibly chemosymbiotic, hexactinellid sponge from the early Cambrian of South China
}

\author{
Joseph P. Botting, Lucy A. Muir, Xiang-Feng Li, and Jih-Pai Lin \\ Acta Palaeontologica Polonica 58 (3), 2012: 641-649 doi: http://dx.doi.org/10.4202/app.2011.0140
}

Six specimens of a strongly curved, cylindrical hexactinellid sponge have been recovered from the Tommotian- Atdabanian Hetang Biota of South China, and are described as Decumbispongia yuani gen. et sp. nov. The robust, thick-walled sponge shows no evidence of an osculum or basal structures, and the body form is inconsistent with an upright, filter-feeding life position. Interpretations as a detritivore feeding by amoeboid extensions, or as a facultative chemosynthetic symbiosis of sponge and bacteria are considered. The latter interpretation is preferred due to the highly constrained body shape, and the body form is interpreted from this perspective. The species indicates that Cambrian sponges occupied at least some autecological niches that appear to have been vacant since that time.

Key words: Porifera, Hexactinellida, symbiosis, chemosynthesis, Cambrian, China.

Joseph P. Botting [acutipuerilis@yahoo.co.uk], Lucy A. Muir [lucy@ asoldasthehills.org ], Xiang-Feng Li [xfeng712@163.com], and Jih-Pai Lin [jplin@nigpas.ac.cn] (corresponding author), State Key Laboratory of Palaeobiology and Stratigraphy, Nanjing Institute of Geology and Palaeontology, Chinese Academy of Sciences, 39 East Beijing Road, Nanjing 210008, China.

This is an open-access article distributed under the terms of the Creative Commons Attribution License (for details please see creativecommons.org), which permits unrestricted use, distribution, and reproduction in any medium, provided the original author and source are credited. 
